\title{
PERFORMA PROPORSI ZERO-INFLATION PADA REGRESI ZERO-INFLATED NEGATIVE BINOMIAL (STUDI KASUS: DATA TETANUS NEONATORUM DI JAWA TIMUR)
}

\author{
Luthfatul Amaliana $^{1 \S}$, Umu Sa'adah ${ }^{2}$, Ni Wayan Surya Wardhani ${ }^{3}$ \\ ${ }^{1}$ Jurusan Matematika, Fakultas MIPA - Universitas Brawijaya [Email: luthfatul@ub.ac.id] \\ ${ }^{2}$ Jurusan Matematika, Fakultas MIPA - Universitas Brawijaya [Email: u.saadah@ub.ac.id] \\ ${ }^{3}$ Jurusan Matematika, Fakultas MIPA - Universitas Brawijaya [Email: wswardhani@ub.ac.id] \\ ${ }^{\S}$ Corresponding Author
}

\begin{abstract}
Tetanus Neonatorum (TN) is an infectious disease that could be prevented by immunization. East Java Province is the highest numbers of TN case in Indonesia. TN data in East Java contain overdispersion and big proportion of zero-inflation (71,05\%). The data containing overdispersion and zero-inflation are more appropriately analyzed by using Zero-Inflated Negative Binomial (ZINB) regression. The aim of this study are: (1) to know the perform of proportion of zero-inflation for ZINB model and (2) to obtain the optimal proportion of zero-inflation for $T N$ data. The result of this study indicates that the optimal proportion of ZINB model is $64,52 \%$.
\end{abstract}

Keywords: Tetanus Neonatorum, zero-inflation, Zero-Inflated Negative Binomial.

\section{PENDAhuluan}

Pembangunan kesehatan di Indonesia melalui Millenium Development Goals (MDGs) berdampak pada turunnya angka kematian balita dari tahun 1990 sampai dengan tahun 2015 hingga dua-pertiganya. Angka Kematian Bayi (AKB) merupakan indikator untuk menilai target penurunan angka kematian balita. Dalam hal ini kematian bayi adalah kematian pada bayi saat lahir sampai dengan sebelum berusia satu tahun (BPS, 2008).

Tingginya AKB di Indonesia sebagian besar diakibatkan oleh persalinan dan penanganan tali pusat yang tidak higienis. Salah satu penyebab utama kematian bayi adalah penyakit Tetanus Neonatorum. Tetanus Neonatorum (TN) adalah tetanus pada bayi usia hari ke-0 sampai dengan 28 hari setelah lahir. Sedangkan Tetanus Maternal (TM) adalah tetanus pada kehamilan dan dalam enam minggu setelah melahirkan. Gejala Tetanus dapat ditandai dengan nyeri otot disebabkan oleh neurotoxin yang dihasilkan Clostridium tetani pada suatu luka tertutup (anaerob) (Kemenkes RI, 2012).
Organisasi kesehatan dunia, WHO bersama dengan UNICEF mengajak negara-negara berkembang di dunia untuk melaksanakan Eliminasi Tetanus Maternal dan Neonatal (ETMN). Sebelum ada pengenalan upaya ETMN, Indonesia merupakan salah satu negara di Asia dengan kasus Tetanuas Neonatorum tertinggi. Berdasarkan data Kementerian Kesehatan (Kemenkes) dalam Profil Kesehatan Indonesia tahun 2015, Jawa Timur merupakan provinsi dengan kasus baru Tetanus Neonatorum tertinggi di Indonesia yaitu 22 kasus. Provinsi dengan kasus baru Tetanus Neonatorum tertinggi ke-2 dan ke-3 adalah Banten dan Kalimantan Barat, dengan masingmasing 12 dan 5 kasus. Secara keseluruhan, Jawa Timur juga merupakan provinsi di Indonesia dengan banyaknya kasus Tetanus Neonatorum tertinggi yaitu 663 kasus (Kemenkes, 2016).

Berkaitan dengan program Kemenkes yang selaras dengan beberapa instansi di Indonesia, Sugiharto dan Ristrini (2016) meneliti profil Tetanus Neonatorum di Kabupaten Bangkalan 
Jawa Timur dalam rangka kebijakan ETMN tahun 2012-2014. Bangkalan merupakan kabupaten dengan banyaknya kasus Tetanus tertinggi di Jawa Timur. Berdasarkan data Dinas Kesehatan Provinsi Jawa Timur, data banyaknya kasus Tetanus Neonatorum di Jawa Timur mengandung proporsi zero-inflation yang cukup besar $(71,05 \%)$. Oleh karena itu, pemodelan banyaknya kasus Tetanus Noenatorum di Jawa Timur membutuhkan suatu metode yang mampu mengakomodir masalah zero-inflation pada data.

Pemodelan data cacah (count) seperti data Tetanus Neonataorum dapat dilakukan salah satunya dengan regresi Poisson. Ketika terjadi overdispersi pada regresi Poisson, regresi Binomial Negatif seringkali menjadi alternatif solusi. Overdispersi adalah suatu kondisi ketika ragam lebih besar dari nilai harapan. Sebaran Binomial Negatif merupakan campuran sebaran Poisson-Gamma (Hilbe, 2011). Pada sebaran Binomial Negatif terdapat suatu parameter dispersi yang mampu mengakomodir terjadinya overdispersi, khususnya pada regresi Poisson (Keswari, dll., 2014). Data cacah banyaknya kasus Tetanus Neonatorum yang mengandung banyak nilai nol atau zero-inflation lebih tepat jika dianalisis dengan regresi Zero-Inflated Negative Binomial (ZINB).

Regresi ZINB memiliki parameter dispersi seperti halnya regresi Binomial Negatif yang berfungsi menggambarkan variasi data. Mulanya, model zero-inflation dikembangkan oleh Lambert (1992) yaitu model Zero-Inflated Poisson (ZIP) pada data banyaknya barang cacat produksi di sebuah industri manufaktur. Namun, proporsi nilai nol (zero-inflation) pada regresi ZIP dikatakan besar jika > 50\%. Beberapa penelitian tentang regresi ZINB dilakukan oleh Astuti dan Mulyanto (2015) untuk memodelkan data banyaknya kasus Tetanus Neonatorum di Jawa Timur tahun 2012. Sedangkan Yusuf, Bello, dan Gureje (2017) memodelkan data banyaknya kasus jatuh pada lansia di Nigeria dengan proporsi zero-inflation sebesar $77,57 \%$ dan mengandung overdispersi menggunakan regresi ZIP dan ZINB. Hasil penelitiannya menunjukkan model regresi ZINB lebih baik dari regresi ZIP.

Fang (2013) meneliti data barisan mikrobiota manusia yang mengandung overdispersi dan zero-inflation dengan regresi ZINB. Data mikroba manusia yang diteliti sedikit berbeda dengan data regresi ZINB pada umumnya, dimana data tersebut merupakan hasil pengukuran berulang yang jelas melibatkan komponen acak di dalamnya. Hasil penelitian Fang menunjukkan bahwa data hasil pengukuran berulang yang mengandung overdispersi dan zero-inflation tetap cocok jika dimodelkan dengan regersi ZINB.

Penelitian-penelitian lainnya antara lain Aa dan Naing (2012) membandingkan regresi Poisson, Binomial Negatif, ZIP, ZINB, dan ZINBD pada data pasien yang terinfeksi AIDS di Kelantan, Malaysia. Hasil penelitian Aa dan Naing menunjukkan bahwa model terbaik untuk kasus tersebut adalah regresi ZeroInflated Negative Binomial Death Rate (ZINBDR). Garay, Hashimoto, Ortega, dan Lachos (2011) meneliti tentang estimasi dan diagnosa titik influensia menggunakan model regresi ZINB. Penelitian Amaliana (2017) membandingkan dua model zero-inflation yaitu regresi ZIP dan ZINB untuk mengetahui model terbaik yang mampu mengatasi overdispersi dan zero-inflation sebesar $73,67 \%$ pada data penyakit Tetanus Neonatorum tahun 2013. Sedangkan Nusantara dan Purhadi (2015) memodelkan data Tetanus Neonatorum di Jawa Timur tahun 2012 yang mengandung 76,31\% proporsi zero-inflation menggunakan regresi Geographically Weighted Zero-Inflated Poisson (GWZIP).

Tujuan penelitian ini adalah: (1) mengetahui performa proporsi zero-inflation pada regresi ZINB dengan melakukan pemodelan pada data Tetanus Neonatorum; (2) mendapatkan proporsi zero-inflation optimal pada regresi ZINB yaitu proporsi zeroinflation yang menghasilkan model ZINB terbaik.

Kasus overdispersi pada data dapat dideteksi dengan membagi nilai devians dengan derajat bebas model. Jika hasil bagi devians dengan derajat bebas bernilai lebih besar dari 1 , 
maka data dikatakan mengandung overdispersi. Sedangkan jika hasil bagi bernilai kurang dari 1, dikatakan terjadi underdispersi pada data. Nilai devians model dapat dinyatakan sebagai (Agresti, 2002):

$$
D=2 \sum_{i=1}^{n} y_{i} \ln \left(\frac{y_{i}}{\hat{\mu}_{i}}\right)
$$

$n$ jumlah pengamatan, $y_{i}$ variabel respon, , $i=1,2, \ldots, n$, dan $\hat{\mu}_{i}$ rataan variabel respon.

Model regresi ZINB merupakan model yang dibentuk dari sebaran campuran PoissonGamma. Model ZINB dapat digunakan untuk memodelkan data cacah yang mengandung banyak nilai nol (zero-inflation) pada variabel respon dan terjadi overdispersi (Garay et all, 2011). Variabel respon $Y_{i} \sim N B\left(\mu_{i}, \kappa\right)$, jika $\pi_{\mathrm{i}}=0$, dengan $0 \leq \pi_{i} \leq 1, \mu_{i} \geq 0$, dan $\kappa$ (kappa) parameter dispersi. Parameter $\mu_{i}$ dan $\pi_{i}$ diasumsikan bergantung pada variabel indeoenden $x_{i}$ yang didefinisikan sebagai:

$$
\mu_{i}=\exp \left(\mathbf{x}_{i}^{T} \beta\right)
$$

$$
\begin{aligned}
& \pi_{i}=\frac{\exp \left(\mathrm{x}_{i}^{T} \gamma\right)}{1+\exp \left(\mathrm{x}_{i}^{T} \gamma\right)} \\
& \left(1-\pi_{i}\right)=\frac{1}{1+\exp \left(\mathrm{x}_{i}^{T} \gamma\right)}
\end{aligned}
$$

Model regresi ZINB dapat dinyatakan dalam model untuk Negative Binomial state $\hat{\mu}_{i}$ dan model untuk zero-inflation state $\hat{\pi}_{i}$, sebagai:

$$
\ln \widehat{\boldsymbol{\mu}}_{i}=\widehat{\boldsymbol{\beta}}_{0}+\sum_{j=1}^{p} \widehat{\boldsymbol{\beta}}_{j} x_{i j}
$$

$$
\operatorname{logit} \widehat{\pi}_{i}=\widehat{\gamma}_{0}+\sum_{j=1}^{p} \widehat{\gamma}_{j} x_{i j}
$$

(6)

$\boldsymbol{p}$ adalah jumlah variabel prediktor, $\widehat{\boldsymbol{\beta}}$ dan $\widehat{\boldsymbol{\gamma}}$ parameter model regresi ZINB yang diduga dengan Maximum Likelihood Estimation dan diselesaikan secara numerik dengan algoritma EM (Ekspektasi-Maksimalisasi).

\section{METODE PENELITIAN}

\section{Sumber Data}

Data yang digunakan dalam penelitian ini adalah data sekunder bersumber dari Profil Kesehatan Provinsi Jawa Timur tahun 2015 yang dipublikasikan oleh Dinas Kesehatan Provinsi Jawa Timur tahun 2016. Data tersebut adalah data banyaknya kasus Tetanus Neonatorum di 38 kabupaten/kota yang meliputi 29 kabupaten dan 9 kota di Jawa Timur.

\section{Jenis Data}

Data sekunder yang digunakan dalam penelitian ini merupakan data cross-sectional dari setiap kabupaten/kota di Jawa Timur pada tahun 2015, yang mencakup data banyaknya kasus baru Tetanus Neonatorum, banyaknya ibu hamil, banyaknya ibu hamil yang sudah imunisasi TT2+, banyaknya ibu bersalin, banyaknya ibu bersalin yang ditolong tenaga kesehatan, banyaknya kunjungan K1 pada ibu hamil, banyaknya ibu hamil yang sudah imunisasi TT1, banyaknya wanita usia subur, dan banyaknya wanita usia subur yang sudah imunisasi TT (Tetanus Toksoid).

\section{Metode Analisis}

Tahapan analisis yang dilakukan pada penelitian ini adalah sebagai berikut:

1. Mendeskripsikan karakteristik data pada setiap variabel, yaitu banyaknya kasus Tetanus Neonatorum, persentase imunisasi TT2+, persentase ibu bersalin ditolong tenaga kesehatan, persentase kunjungan K1, persentase imunisasi TT1, dan persentase imunisasi TT pada wanita usia subur,

2. Melakukan analisis deskriptif pada variabel respon (Y) dan variabel-variabel prediktor (X) sebagai gambaran awal kasus Tetanus Neonatorum,

3. Memeriksa proporsi zero-inflation pada data Tetanus Naonatorum,

4. Mengidentifikasi overdispersi dengan melihat nilai devians model,

5. Mengidentifikasi multikolinieritas dengan melihat kriteria VIF dan menanganinya jika terjadi multikolinieritas. Nilai VIF dirumuskan sebagai (Gujarati, 2004):

$$
V I F_{j}=\frac{1}{\left(1-R_{j}^{2}\right)}
$$

$R_{j}^{2}$ adalah koefisien determinasi antara $\mathrm{X}_{j}$ dengan variabel prediktor lainnya. 
6. Menentukan proporsi zero-inflation dari data Tetanus Neonatorum,

7. Melakukan pemodelan dengan regresi ZINB untuk setiap proporsi zero-inflation pada data Tetanus Neonatorum menggunakan software R,

8. Membandingkan nilai AIC dari semua model ZINB yang terbentuk dan menentukan model terbaik menggunakan kriteria nilai Akaike Information Criterion: $\mathrm{AIC}=-2 \ln ($ maks likelihood $)+2(n)$

9. Melakukan pendugaan parameter dan pengujian hipotesis pada model ZINB terbaik,

10.Melakukan interpretasi model terbaik dengan proporsi optimal zero-inflation.

\section{HASIL DAN PEMBAHASAN}

\section{Histogram Data Banyaknya Kasus Tetanus Neonatorum}

Pada penelitian ini, variabel respon yang digunakan adalah banyaknya kasus baru Tetanus Neonatorum di Jawa Timur tahun 2015. Secara keseluruhan, kasus Tetanus Neonatorum terjadi di 11 kabupaten/kota di Jawa Timur yaitu sebanyak 22 kasus. Histogram data banyaknya kasus Tetanus Neonatorum dapat dilihat pada Gambar 1.

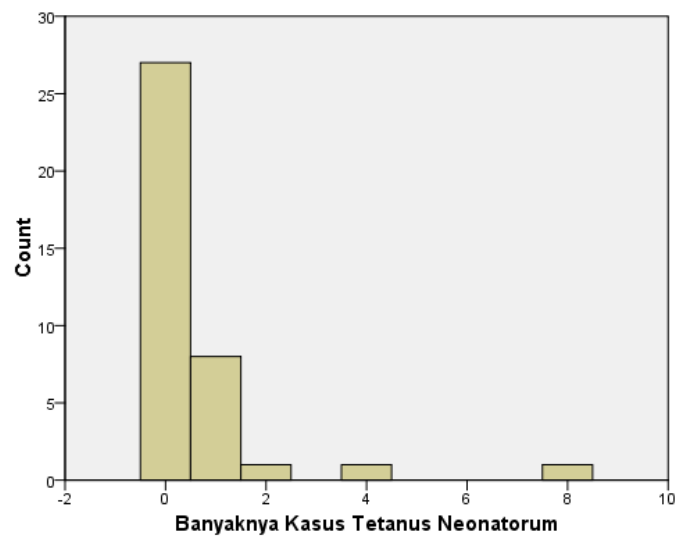

Gambar 1. Histogram Data Banyaknya Kasus Tetanus Neonatorum

Histogram pada gambar 1 menunjukkan bahwa data cacah banyaknya kasus Tetanus Neonatorum berkisar antara nol sampai dengan delapan kasus.

\section{Analisis Deskriptif Variabel}

Variabel-variabel prediktor yang digunakan dalam penelitian ini yaitu persentase imunisasi TT2+ $\left(\mathrm{X}_{1}\right)$, persentase ibu bersalin ditolong tenaga kesehatan $\left(\mathrm{X}_{2}\right)$, persentase kunjungan K1 $\left(X_{3}\right)$, persentase imunisasi TT1 $\left(X_{4}\right)$, dan persentase imunisasi TT pada wanita usia subur $\left(\mathrm{X}_{5}\right)$. Analisis deskriptif dari variabel respon dan variabel-variabel prediktor dirangkum dalam Tabel 1 berikut.

Tabel 1. Analisis Deskriptif Variabel

\begin{tabular}{|c|c|c|c|c|}
\hline Var & Rata-rata & StdDev & Min & Maks \\
\hline $\mathrm{Y}$ & 0,579 & 1,464 & 0 & 8 \\
\hline $\mathrm{X}_{1}$ & 47,720 & 52,980 & 0 & 281,90 \\
\hline $\mathrm{X}_{2}$ & 95,048 & 3,849 & 86,150 & 100,65 \\
\hline $\mathrm{X}_{3}$ & 99,724 & 4,004 & 91,900 & 109,40 \\
\hline $\mathrm{X}_{4}$ & 2,910 & 6,280 & 0 & 32,33 \\
\hline $\mathrm{X}_{5}$ & 26,310 & 46,740 & 0 & 257,71 \\
\hline
\end{tabular}

Tabel 1 menunjukkan bahwa pada tahun 2015, kasus Tetanus Neonatorum tertinggi di Jawa Timur adalah 8 kasus dan rata-rata kejadian Tetanus Neonatorum di seluruh kabupaten/kota di Jawa Timur sebesar 0,579.

Berdasarkan Tabel 1, dapat diketahui bahwa rata-rata persentase ibu bersalin yang ditolong tenaga kesehatan dan rata-rata persentase ibu hamil yang mendapat kunjungan K1 sudah cukup tinggi di setiap kabupaten/kota di Jawa Timur, yaitu masing-masing mencapai lebih dari $95 \%$ dan $99 \%$. Sedangkan rata-rata persentase ibu hamil yang mendapat imunisasi TT1 cukup rendah yaitu hanya $2,91 \%$. Hal ini dapat disebabkan pada umumnya ibu hamil tidak hanya mendapat imunisasi TT1 saja, tetapi sampai dengan TT2+.

\section{Identifikasi Proporsi Zero-Inflation}

Data Tetanus Neonatorum mengandung banyak nilai nol (zero-inflation). Oleh karena itu, dilakukan identifikasi besarnya proporsi zero-inflation pada data Tetanus Neonatorum di Jawa Timur tersebut. Hasil identifikasi proporsi zero-inflation dirangkum dalam Tabel 2. 
Tabel 2. Hasil Identifikasi Proporsi Zero-Inflation

\begin{tabular}{|c|c|c|c|}
\hline Kasus TN & Frekuensi & $\boldsymbol{\%}$ & \% Kumulatif \\
\hline 0 & 27 & $71,05 \%$ & $71,05 \%$ \\
\hline 1 & 8 & $21,05 \%$ & $92,11 \%$ \\
\hline 2 & 1 & $2,63 \%$ & $94,74 \%$ \\
\hline 4 & 1 & $2,63 \%$ & $97,37 \%$ \\
\hline 8 & 1 & $2,63 \%$ & $100,00 \%$ \\
\hline
\end{tabular}

Berdasarkan Tabel 2, dapat diketahui bahwa data banyaknya kasus Tetanus Neomatorum mengandung proporsi zero-inflation yang cukup besar yaitu $71,05 \%$. Berdasarkan data Dinas Kesehatan Jawa Timur, kasus Tetanus Neonatorum tertinggi terjadi di Kabupaten Bangkalan (8 kasus) dan Kabupaten Sampang (4 kasus).

Tabel 2 hasil identifikasi proporsi ZeroInflation juga menunjukkan di sebanyak 27 dari total 38 kabupaten/ kota di Jawa Timur tidak terjadi kasus Tetanus Neonatorum (0 kasus).

\section{Identifikasi Overdispersi}

Salah satu cara untuk mengidentifikasi adanya overdispersi adalah melihat hasil bagi devians dengan derajat bebas model. Nilai devians, derajat bebas, dan hasil bagi keduanya dirangkum dalam Tabel 3.

Tabel 3. Hasil Identifikasi Overdispersi

\begin{tabular}{|c|c|c|}
\hline Devians & d.f. & Devians / d.f. \\
\hline 38,13502 & 32 & 1,192 \\
\hline
\end{tabular}

Berdasarkan Tabel 3, dapat diketahui bahwa hasil bagi devians dengan derajat bebas model bernilai lebih besar dari 1. Hal ini menunjukkan terjadi overdispersi pada data banyaknya kasus Tetanus Neonatorum di Jawa Timur tahun 2015.

\section{Identifikasi Mulikolinieritas}

Multikolinieritas merupakan suatu kondisi dimana terdapat korelasi tinggi antar variabel-variabel prediktor. Kondisi ini dapat mengakibatkan hasil pendugaan parameter menjadi tidak akurat. Multikolinieritas dapat diidentifikasi dengan melihat nilai Variance Inflating Factor (VIF) yang lebih dari 10. Nilai VIF menunjukkan bagaimana variansi hasil pendugaan parameter akan meningkat disebabkan adanya kasus multikolinieritas. Nilai VIF dari setiap variabel prediktor dalam penelitian ini dirangkum dalam Tabel 4.

Tabel 4. Hasil Identifikasi Multikolinieritas

\begin{tabular}{|c|c|c|c|c|c|}
\hline & $\mathrm{X}_{1}$ & $\mathrm{X}_{2}$ & $\mathrm{X}_{3}$ & $\mathrm{X}_{4}$ & $\mathrm{X}_{5}$ \\
\hline VIF & 1,597 & 6,723 & 7,367 & 1,789 & 1,341 \\
\hline
\end{tabular}

Tabel 4 menunjukkan bahwa semua variabel prediktor memiliki nilai VIF $<10$. Hal ini mengindiksikan tidak terdapat multikolinieritas antar variabel prediktor.

\section{Penentuan Proporsi Zero-Inflation}

Setelah dilakukan identifikasi proporsi zeroinflation, overdispersi, dan multikolinieritas, selanjutnya akan ditentukan beberapa proporsi zero-inflation pada data Tetanus Neonatorum di Jawa Timur untuk mengetahui proporsi zeroinflation terbaik pada regresi ZINB. Penentuan proporsi zero-inflation ini dilakukan dengan mengurangi secara random satu per satu data yang mengandung nilai nol (tidak ada kejadian Tetanus Nenoatorum atau $\mathrm{Y}=0$ kasus). Jumlah sampel data yang awalnya 38 dengan proporsi zero-inflation sebesar $71,05 \%$ (27 dari 38 kabupaten/kota) berkurang menjadi 37 sampel dengan proporsi zero-inflation sebesar 70,27\% (26 dari 37 kabupaten/kota). Penentuan proporsi zero-inflation ini dilakukan sampai dengan jumlah sampel minimal lebih besar dari 30 . Hasil penentuan proporsi zero-inflation dirangkum pada Tabel 5.

Tabel 5. Proporsi Zero-Inflation

\begin{tabular}{|c|c|c|}
\hline Model & Proporsi (\%) & Sampel \\
\hline 1 & $71,05 \%$ & 38 \\
\hline 2 & $70,27 \%$ & 37 \\
\hline 3 & $69,44 \%$ & 36 \\
\hline 4 & $68,57 \%$ & 35 \\
\hline 5 & $67,65 \%$ & 34 \\
\hline 6 & $66,67 \%$ & 33 \\
\hline 7 & $65,63 \%$ & 32 \\
\hline 8 & $64,52 \%$ & 31 \\
\hline
\end{tabular}

Tabel 5 menunjukkan bahwa terdapat 8 proporsi zero-inflation yang berbeda untuk setiap model ZINB yang akan dibentuk. Proporsi zero-inflation terbesar sesuai dengan jumlah 
sampel data awal adalah $71,05 \%$ dan terkecil adalah $64,52 \%$.

\section{Pemodelan Banyaknya Kasus Tetanus Neonatorum dengan Regresi ZINB pada Berbagai Proporsi Zero-Inflation}

Langkah selanjutnya setelah ditentukan beberapa proporsi zero-inflation adalah melakukan pemodelan banyaknya kasus Tetanus Neonatorum dengan regresi ZINB untuk setiap proporsi zero-inflation. Tabel 6 berikut merangkum perbandingan nilai loglikelihood dan variabel-variabel prediktor yang signifikan dari hasil pemodelan ZINB pada setiap proporsi zero-inflation.

Tabel 6. Perbandingan Hasil Pemodelan ZINB

\begin{tabular}{|c|c|c|c|c|}
\hline & \multirow{2}{*}{ Model } & \multirow{2}{*}{$\begin{array}{c}\text { Proporsi } \\
(\%)\end{array}$} & $\begin{array}{c}\text { Log- } \\
\text { Likeli } \\
\text { hood }\end{array}$ & \multicolumn{2}{|c|}{\begin{tabular}{c} 
Variabel Signifikan \\
$(\alpha=5 \%)$ \\
\cline { 4 - 5 }
\end{tabular}} & & $\begin{array}{c}\text { Model } \\
\text { NB State }\end{array}$ & $\begin{array}{c}\text { Model } \\
\text { ZI } \\
\text { State }\end{array}$ \\
\hline 1 & $71,05 \%$ & $-24,00$ & $\begin{array}{c}* \mathrm{X}_{1}, \mathrm{X}_{2}, \\
\mathrm{X}_{3}, \mathrm{X}_{4}\end{array}$ & $* \mathrm{X}_{3}$ \\
\hline 2 & $70,27 \%$ & $-23,96$ & $\begin{array}{c}* \mathrm{X}_{1}, \mathrm{X}_{2}, \\
\mathrm{X}_{3}, \mathrm{X}_{4}\end{array}$ & $* \mathrm{X}_{3}$ \\
\hline 3 & $69,44 \%$ & $-23,95$ & $\mathrm{X}_{2}, \mathrm{X}_{3}, \mathrm{X}_{4}$ & $* \mathrm{X}_{3}$ \\
\hline 4 & $68,57 \%$ & $-22,33$ & $\mathrm{X}_{2}, \mathrm{X}_{3}, \mathrm{X}_{4}$ & - \\
\hline 5 & $67,65 \%$ & $-23,33$ & $\mathrm{X}_{2}, \mathrm{X}_{3}, \mathrm{X}_{4}$ & - \\
\hline 6 & $66,67 \%$ & $-23,30$ & $\mathrm{X}_{2}, \mathrm{X}_{3}, \mathrm{X}_{4}$ & - \\
\hline 7 & $65,63 \%$ & $-23,29$ & $\mathrm{X}_{2}, \mathrm{X}_{3}, \mathrm{X}_{4}$ & - \\
\hline 8 & $64,52 \%$ & $-23,29$ & $\mathrm{X}_{2}, \mathrm{X}_{3}, \mathrm{X}_{4}$ & - \\
\hline
\end{tabular}

*) $\alpha=10 \%$

Berdasarkan perbandingan hasil pemodelan ZINB pada Tabel 6, dapat diketahui bahwa variabel $\mathrm{X}_{2}, \mathrm{X}_{3}$, dan $\mathrm{X}_{4}$ signifikan pada model Negative Binomial state untuk semua proporsi zero-inflation serta tidak ada variabel yang signifikan pada model zero-inflation state dengan tingkat signifikansi 0,05 . Sedangkan pada tingkat signifikansi 0,10 , variabel $\mathrm{X}_{1}, \mathrm{X}_{2}$, $\mathrm{X}_{3}, \quad \mathrm{X}_{4}$ signifikan untuk model Negative Binomial state 1 dan 2 , serta variabel $\mathrm{X}_{3}$ signifikan pada model zero-inflation state.

\section{Penentuan Model ZINB Terbaik}

Pada penelitian ini akan ditentukan model ZINB terbaik dengan proporsi zero-inflation paling optimal untuk memodelkan data Tetanus Neonatorum di Jawa Timur tahun 2015.
Kriteria yang digunakan untuk menentukan model terbaik menggunakan nilai AIC. Tabel 7 berikut adalah rangkuman dari perbandingan nilai AIC untuk setiap proporsi zero-inflation.

Tabel 7. Perbandingan Nilai AIC

\begin{tabular}{|c|c|c|c|}
\hline Model & Proporsi (\%) & Devians & AIC \\
\hline 1 & $71,05 \%$ & 48,00 & 74,00883 \\
\hline 2 & $70,27 \%$ & 47,92 & 73,92293 \\
\hline 3 & $69,44 \%$ & 47,90 & 73,90902 \\
\hline 4 & $68,57 \%$ & 44,66 & 70,66935 \\
\hline 5 & $67,65 \%$ & 46,66 & 72,65516 \\
\hline 6 & $66,67 \%$ & 46,60 & 72,59437 \\
\hline 7 & $65,63 \%$ & 46,58 & 72,58576 \\
\hline 8 & $64,52 \%$ & 46,58 & 72,58093 \\
\hline
\end{tabular}

Nilai AIC dan devians model pada Tabel 7 menunjukkan bahwa nilai AIC semakin kecil ketika proporsi zero-inflation semakin kecil sampai dengan proporsi zero-inflation $68,57 \%$. Berdasarkan hasil pemodelan ZINB pada semua proporsi zero-inflation, dapat diketahui bahwa model ZINB terbaik adalah model 4 dengan proporsi zero-inflation sebesar $68,57 \%$ dan nilai AIC terkecil.

\section{Pendugaan Parameter dan Uji Hipotesis}

Penduga parameter yang diperoleh dari hasil pemodelan banyaknya kasus Tetanus Neonatorum dengan proporsi zero-inflation sebesar $68,57 \%$ dituliskan dalam Tabel 8 .

Tabel 8. Hasil Pendugaan Parameter Regresi ZINB dengan Proporsi Zero-Inflation 68,57\%

\begin{tabular}{|c|r|c|r|c|}
\hline $\begin{array}{c}\text { Para } \\
\text { meter }\end{array}$ & Estimasi & SE & Z-hit & $\operatorname{Pr}(>|\mathbf{z}|)$ \\
\hline$\hat{\beta}_{0}$ & $-9,964$ & 8,162 & $-1,221$ & 0,222146 \\
\hline$\hat{\beta}_{1}$ & $-0,019$ & 0,014 & $-1,307$ & 0,191343 \\
\hline$\hat{\beta}_{2}$ & 0,364 & 0,099 & 3,688 & $0,000226^{*}$ \\
\hline$\hat{\beta}_{3}$ & $-0,246$ & 0,093 & $-2,658$ & $0,007871^{*}$ \\
\hline$\hat{\beta}_{4}$ & 0,098 & 0,029 & 3,352 & $0,000802^{*}$ \\
\hline$\hat{\beta}_{5}$ & 0,005 & 0,007 & 0,656 & 0,511963 \\
\hline$\hat{\gamma}_{0}$ & $-2,255$ & NA & NA & NA \\
\hline$\hat{\gamma}_{1}$ & $-1,160$ & NA & NA & NA \\
\hline$\hat{\gamma}_{2}$ & 66,517 & NA & NA & NA \\
\hline$\hat{\gamma}_{3}$ & $-63,371$ & NA & NA & NA \\
\hline$\hat{\gamma}_{4}$ & $-50,890$ & NA & NA & NA \\
\hline$\hat{\gamma}_{5}$ & 1,959 & NA & NA & NA \\
\hline \multicolumn{5}{|c|}{ Log-Kappa $=20,589$} \\
\multicolumn{5}{|c|}{ Log-likelihood = -22,33; df = 13 } \\
\hline
\end{tabular}

*) $\alpha=5 \%$ 
Tabel 8 menunjukkan bahwa standar error, nilai Z-hitung dan $\operatorname{Pr}(>|z|)$ tidak ada nilainya (Not Available/NA). Hal ini dikarenakan iterasi pada penyelesaian metode MLE dengan algoritma EM tidak mencapai titik konvergen untuk model zero-inflation state. Oleh karena itu, semua penduga parameter pada zeroinflation state tidak dapat dimodelkan dan model ZINB dengan proporsi $68,57 \%$ bukan model terbaik dalam studi kasus ini. Berdasarkan nilai AIC dan devians model pada Tabel 7, model ZINB terbaik adalah model 8 dengan proporsi zero-inflation sebesar $64,52 \%$. Hasil pendugaan parameter model ZINB dengan proporsi zero-inflation $64,52 \%$ dirangkum dalam Tabel 9.

Tabel 9. Hasil Pendugaan Parameter Regresi ZINB dengan Proporsi Zero-Inflation 64,52\%

\begin{tabular}{|c|r|r|r|l|}
\hline $\begin{array}{c}\text { Para } \\
\text { meter }\end{array}$ & Estimasi & \multicolumn{1}{c|}{ SE } & Z-hitung & $\operatorname{Pr}(>|\mathbf{z}|)$ \\
\hline$\hat{\beta}_{0}$ & 2,596 & 10,041 & 0,259 & 0,795984 \\
\hline$\hat{\beta}_{1}$ & $-0,026$ & 0,016 & $-1,602$ & 0,109152 \\
\hline$\hat{\beta}_{2}$ & 0,265 & 0,094 & 2,799 & $0,005119^{*}$ \\
\hline$\hat{\beta}_{3}$ & $-0,271$ & 0,100 & $-2,706$ & $0,006803^{*}$ \\
\hline$\hat{\beta}_{4}$ & 0,113 & 0,032 & 3,500 & $0,000466^{*}$ \\
\hline$\hat{\beta}_{5}$ & 0,008 & 0,008 & 1,040 & 0,298236 \\
\hline$\hat{\gamma}_{0}$ & 31,214 & 27,330 & 1,142 & 0,253 \\
\hline$\hat{\gamma}_{1}$ & $-0,080$ & 0,055 & $-1,453$ & 0,146 \\
\hline$\hat{\gamma}_{2}$ & 1,073 & 0,832 & 1,289 & 0,197 \\
\hline$\hat{\gamma}_{3}$ & $-1,309$ & 0,827 & $-1,583$ & 0,113 \\
\hline$\hat{\gamma}_{4}$ & $-0,568$ & 0,399 & $-1,423$ & 0,155 \\
\hline$\hat{\gamma}_{5}$ & 0,048 & 0,031 & 1,523 & 0,128 \\
\hline \multicolumn{5}{|c|}{ Log-Kappa =14,7104 } \\
\hline \multicolumn{5}{|c|}{ AIC = 72,58093 } \\
\hline$\alpha=5 \%$-likelihood = -23,29; df =13 \\
\hline
\end{tabular}

*) $\alpha=5 \%$

Hasil pendugaan parameter pada Tabel 9 menunjukkan bahwa banyaknya kasus Tetanus Neonatorum berhubungan dengan persentase ibu bersalin ditolong tenaga kesehatan $\left(\mathrm{X}_{2}\right)$, persentase kunjungan $\mathrm{K} 1\left(\mathrm{X}_{3}\right)$, dan persentase imunisasi TT1 $\left(\mathrm{X}_{4}\right)$, pada tingkat signifikansi $\alpha$ $=0,05$ model NB state. Namun, tidak ada variabel prediktor yang signifikan pada model zero-inflation state.

Berdasarkan uji signifikansi parameter secara simultan menggunakan statistik uji $\mathrm{G}$, diperoleh $\mathrm{G}=-2$ (Log-likelihood) $=-2(-$ $23,29)=46,58$ dan nilai Chi-Square tabel dengan $\mathrm{df}=13$ adalah $\chi^{2}=22,36203$. Dengan demikian, dapat dikatakan bahwa secara simultan semua variabel prediktor dalam regresi ZINB berpengaruh signifikan terhadap banyaknya kasus Tetanus Neonatorumdi Jawa Timur tahun 2015.

\section{Interpretasi Model}

Model regresi ZINB terbaik dengan proporsi zero-inflation sebesar $64,52 \%$, dapat dituliskan dalam bentuk model Negative Binomial state dan model Zero-Inflation state sebagai berikut:

\section{(i) Model Negative Binomial State}

$\hat{\mu}=\exp \left(\hat{\beta}_{0}+\hat{\beta}_{1} X_{1}+\hat{\beta}_{2} X_{2}+\hat{\beta}_{3} X_{3}+\hat{\beta}_{4} X_{4}+\hat{\beta}_{5} X_{5}\right)$

dengan

$\hat{\beta}_{0}=2,596$

$\hat{\beta}_{3}=-0,271$

$\hat{\beta}_{1}=-0,026$

$\hat{\beta}_{4}=0,113$

$\hat{\beta}_{2}=0,265$

$\hat{\beta}_{5}=0,008$

(ii) Model Zero-Inflation State

$\hat{\pi}=\frac{\exp \left(\widehat{\gamma}_{0}+\widehat{\gamma}_{1} X_{1}+\widehat{\gamma}_{2} X_{2}+\widehat{\gamma}_{3} X_{3}+\widehat{\gamma}_{4} X_{4}+\widehat{\gamma}_{5} X_{5}\right)}{1+\exp \left(\widehat{\gamma}_{0}+\widehat{\gamma}_{1} X_{1}+\widehat{\gamma}_{2} X_{2}+\widehat{\gamma}_{3} X_{3}+\widehat{\gamma}_{4} X_{4}+\widehat{\gamma}_{5} X_{5}\right)}$

dengan:

$$
\begin{array}{ll}
\hat{\gamma}_{0}=31,214 & \hat{\gamma}_{3}=-1,309 \\
\hat{\gamma}_{1}=-0,080 & \hat{\gamma}_{4}=-0,568 \\
\hat{\gamma}_{2}=1,073 & \hat{\gamma}_{5}=0,048
\end{array}
$$

Semua variabel prediktor pada model (ii) tidak signifikan terhadap variabel respon, dengan tingkat signifikansi $\alpha=0,05$. Oleh karena itu, hanya model (i) yang akan diinterpretasikan dimana persentase ibu bersalin ditolong tenaga kesehatan $\left(\mathrm{X}_{2}\right)$, persentase kunjungan $\mathrm{K} 1\left(\mathrm{X}_{3}\right)$, dan persentase imunisasi TT1 $\left(\mathrm{X}_{4}\right)$ signifikan di dalam model.

Berdasarkan model (i), rata-rata banyaknya kasus Tetanus Neonatorum diekspektasikan akan meningkat sebesar $\exp (0,265)=1,303 \mathrm{kali}$ dari banyaknya kasus semula untuk setiap penambahan satu persen ibu bersalin ditolong tenaga kesehatan $\left(\mathrm{X}_{2}\right)$, akan menurun sebesar $\exp (0,271)=1,311$ kali dari banyaknya kasus semula untuk setiap penambahan satu persen kunjungan $\mathrm{K} 1$ pada ibu hamil $\left(\mathrm{X}_{3}\right)$, dan akan meningkat $\exp (0,113)=1,119$ kali dari 
banyaknya kasus semula untuk setiap penambahan satu persen imunisasi TT1 pada ibu hamil $\left(\mathrm{X}_{2}\right)$, jika variabel lain dianggap konstan.

\section{KESIMPULAN DAN SARAN}

\section{Kesimpulan}

Berdasarkan hasil pemodelan banyaknya kasus Tetanus Neonatorum di Jawa Timur menggunakan regresi ZINB pada berbagai proporsi zero-inflation, diperoleh simpulan sebagai berikut:

1. Proporsi zero-inflation sebesar $64,52 \%$ pada data banyaknya kasus Tetanus Neonatorum di Jawa Timur merupakan proporsi optimal yang menghasilkan model ZINB terbaik berdasarkan kriteria AIC.

2. Variabel prediktor persentase ibu bersalin yang ditolong tenaga kesehatan, persentase kunjungan K1 pada ibu hamil, dan persentase imunisasi TT1 pada ibu hamil berpengaruh signifikan terhadap banyaknya kasus Tetanus Neonatorum di Jawa Timur.

\section{Saran}

Saran untuk penelitian selanjutnya adalah dapat dicari proporsi zero-inflation optimal yang berlaku umum untuk semua kasus menggunakan regresi ZINB. Proporsi zero-inflation optimal yang diperoleh dalam penelitian ini merupakan hasil dari satu studi kasus data Tetanus Neonatorum di Jawa Timur.

\section{UCAPAN TERIMA KASIH}

Penelitian ini didanai oleh dana BOPTN Nomor 27/UN10.F09.01/PN/2017 Fakultas MIPA Universitas Brawijaya, Malang, Indonesia. Ucapan terima kasih ini ditujukan kepada semua pihak yang terkait sehingga penelitian ini dapat terlaksana dengan baik.

\section{DAFTAR PUSTAKA}

Aa, M.A., \& Naing, N.N. (2012). Analysis Death Rate of Age Model with Excess Zeros using ZINB and Negative Binomial Death Rate: Mortality AIDS Co-infection Patients, Kelantan Malaysia. Procedia Economics and Finance. 2. Hal. 275-283.
Agresti, A. (2002). Categorical Data Analysis. Edisi 2. John Wiley \& Sons. New York.

Amaliana, L. (2017). Perbandingan ZIP dan ZINB pada jumlah kasus tetanus neonatorum di Jawa Timur tahun 2013. Prosiding Seminar Nasional Matematika Indo-MS Wilayah Sulawesi. 11-12 Juli 2017, Makassar, Indonesia. Hal. 428-438.

Astuti, C.C., Mulyanto, A.D. (2016). Pemodelan Regresi ZINB pada Kasus Tetanus Neonatorum di Provinsi Jawa Timur. Cauchy-Jurnal Matematika Murni dan Aplikasi. 4 (3). Hal. 115-119.

Badan Pusat Statistik. (2008). Data dan Informasi Kemiskinan 2008. Jakarta: BPS.

Dinas Kesehatan Provinsi Jawa Timur. (2016). Profil Kesehatan Provinsi Jawa Timur Tahun 2015. Dinas Kesehatan Jawa Timur. Surabaya.

Fang, R. (2013). ZINB Regression Model for Overdispersed Count Data with Excess Zeros and Repeated Measures, An Application to Human Microbiota Sequence Data. Tesis. Biostatistics Program. University of Colorado.

Garay, A.M., Hashimoto, E.M., Ortega, E.M.M., \& Lachos, V.H. (2011). On Estimation and Influence Diagnostics for ZINB Regression Models. Computational Statistics and Data Analysis. 55 (2011). Hal. 1304-1318.

Gujarati, D. N. (2004). Basic Econometrics, $4^{\text {th }}$ $E d$. Mc.Graw-Hill Companies, New York.

Hilbe, J.M. (2011). Negative Binomial Regression, $2^{\text {th }} E d$. Cambridge University Press. New York.

Kementerian Kesehatan RI. (2012). Eliminasi Tetanus Maternal dan Neonatal. Buletin Jendela Data dan Informasi Kesehatan. I, September 2017.

Kementerian Kesehatan RI. (2016). Profil Kesehatan Indonesia Tahun 2015. Kementerian Kesehatan RI. Jakarta.

Keswari, N.M.R., Sumarjaya, I.W., \& Suciptawati, N.L.P. (2014). Perbandingan Regresi NB dan Regresi Generalisasi Poisson dalam Mengatasi Overdispersi. E-Jurnal Matematika. 3 (3). Hal. 107-115.

Lambert, D. (1992). Zero-Inflated Poisson Regression, with an Application to Defect in Manufacturing. American Statistical 
Assosiation and the American Society for Quality Control. 34 (1). Hal. 1-14.

Nusantara, R.K.P. \& Purhadi.(2015). Pemodelan Jumlah Kasus Penyakit Tetanus Neonatorum di Jawa Timur Tahun 2012 dengan GWZIPR. E-Jurnal Sains dan Seni ITS. 4 (1). Hal. 79-84.
Sugiharto \& Ristrini. (2016). Profil Tetanus Neonatorum dalam Rangka Kebijakan ETMN di Kabupaten Bangkalan Jawa Timur 2012 - 2014. Buletin Penelitian Sistem Kesehatan. 19 (2). Hal.149-156.

Yusuf, O.B., Bello, T., \& Gureje, O. (2017). ZIP and ZINB Models with Application to Number of Falls in the Elderly. Biostatistics \& Biometrics. 1 (4). Hal. 1-7. 